\title{
On Using Languages other Than the Target One in L2 Adult Language Education: Teachers' Views and Practices in Modern Greek Classrooms
}

\author{
Vicky Kantzou, Dimitra Maria Vasileiadi \\ Hellenic Open University
}

\begin{abstract}
Correspondence concerning this article should be addressed to Vicky Kantzou, Faculty of Humanities, Hellenic Open University, Aristotelous 18, Patra 263 35, Greece. E-mail: vickykantzou@hotmail.com
\end{abstract}

\begin{abstract}
Current developments in language education call for a reassessment of the role that students already-established linguistic repertoires can play in language teaching. This study probed into adult second language education in Modern Greek offered in Greece, where classes are culturally and linguistically diverse. We investigated teachers' views and perceived practices regarding the use of other languages in their classes. A mixed-method design was followed. Data on teachers' opinions was collected via a questionnaire completed by 30 teachers. Complementary data on teachers' practices collected through observations of two classes was also studied. The results indicated that English was mainly used by the teachers as a mediation language, although a wide variation was reported in the amount of other-language use. Large variations were also reported in the students' behaviour. Teachers stressed several benefits from using other languages in class, but also expressed concerns about excessive reliance on other languages and on how using a support language would impact students with limited proficiency in this language. These findings were discussed in light of recent developments in language education and implications for teacher training were considered.
\end{abstract}

Keywords: language education, other-language use, Modern Greek, multilingual classes, adults

\section{Introduction}

The use of languages other than the target one in the process of teaching and learning a second language (L2) has been viewed as a practice to be avoided since the time of the 'Great Reform' and especially under the influence of the Direct Method (V. Cook, 2001; Hall \& Cook, 2012; Howatt, 1984). The tradition of monolingual teaching survived the overhaul of second language teaching methods during the 20th century. During this period, as Hall and Cook observed (2013: 278), limited reference was made to the role of other languages, and the issue had been marginalised in the relevant discourse. However, in recent years, monolingual teaching has been challenged by both shifting theoretical perspectives and research on classroom practice. Students' and teachers' first languages (L1) have emerged as a valuable resource in teaching and learning (Butzkamm \& Caldwell, 2009; V. Cook, 2001; Cummins 2007; M. Turnbull \& Dailey-O’Cain, 2009).

Nevertheless, language classrooms in many contexts are culturally and linguistically diverse and the student population is quite heterogeneous in terms of their L1. The utilisation of students' and teachers' full linguistic repertoires, including languages other than their L1, in the process of teaching and learning an additional language have been scantily investigated (B. Turnbull, 2018). A few relevant studies have focused on English as a lingua franca in language classes (B. Turnbull, 2018; Ife, 2008; Wang, 2013), showing that English in these contexts served functions similar to the L1 in linguistically homogeneous classes.

Against this background, the present study probed into adult second language education and Modern Greek teachers' views and practices regarding the use of languages other than the target one in their classes, where the composition of the learners' population was a multicultural and multilingual mix (Psaltou-Joycey, 2008). The institutions approached for data collection do not pose any requirements for student enrolment in terms 
of other-language knowledge (e.g., English); therefore, the existence of common languages among the students and the teacher cannot been taken for granted.

Investigating what teachers know, think, and believe, allows us to gain an understanding of their instructional decisions. Teacher cognition, shaped by a variety of factors ranging from teachers' professional education to their own experiences as students, has been found to influence their classroom practice (Borg, 2003). In parallel, complementary data on teachers' practices collected through observations were studied. The results of this study are expected to have important implications for teacher training and life-long professional development.

\section{Literature Review}

\section{A Place for Students' Already-Established Linguistic Repertoires in the Classroom}

While the direct method promoted the exclusive use of the target language in classes (Hall \& Cook, 2012; Richards \& Rodgers, 2014), subsequent approaches to language teaching rarely abolished the use of students' own first language altogether. However, great emphasis was placed on maximising L2 use, as language input (Krashen, 1985) and negotiation of meaning (Long, 1996) were considered critical for language acquisition. Therefore, "[t]he L1 is not something to be utilised in teaching but to be set aside" (V. Cook, 2001, p. 404), as it reduces students' exposure to the L2 or, in the case of the students, is considered an indication of off-task behaviour (Macaro, 2005).

Despite these recommendations, there have been voices acknowledging that the use of students' own first languages is an inescapable fact in language classes. An abundance of studies has shown that classroom interaction includes the use of students' first languages by both the teachers and the students (for a review of the literature, see Hall \& Cook, 2012). In fact, as Levine (2011) observed from his own teaching experience, the more control students have over the content and direction of classroom communication, the more likely they are to employ their L1. The allowance for L1 use has been shown to have psychological benefits for the students as it can play a "reassuring" role in the L2 classroom, helping to reduce students' anxiety and increase security (Butzkamm \& Caldwell, 2009; Levine, 2003; Littlewood \& Yu, 2011). The L1 can also be used as a metacommunication tool by the students (Storch \& Aldosari 2010; Storch \& Wigglesworth, 2003); Swain and Lapkin (2000) showed that it is the code employed for structuring and organising tasks in classes. As Macaro (2005) pointed out, students often lack the language necessary to manage a task and therefore they deploy their full linguistic repertoire as a compensatory communication strategy.

As far as the teachers are concerned, they resort to the students' first language for a variety of functions. M. Turnbull (2000, as cited in M. Turnbull \& Arnett, 2002) distinguished between academic, managerial, and social purposes, while Littlewood and $\mathrm{Yu}$ (2011), along the same lines, made a distinction between "core goals", i.e., teaching the target language, and "framework goals", i.e., the use of language for affective and interpersonal support, and as an aid to classroom management. Each of these "macro-categories" (Turnbull, 2000, as cited in M. Turnbull \& Arnett, 2002) included a repertoire of functions. For instance, core goals include explaining a complex grammar point and providing a translation for an unknown word, while classroom management covers functions such as providing instructions for classroom activities and setting the homework.

Teachers have reported considering the use of students' L1 as "unfortunate and regrettable but necessary" (Macaro, 2005, p. 68), while their attitudes towards its use have been found to be subject to change with time and experience, as they gradually recognise that the L1 can be a valuable resource in teaching (Hall \& Cook, 2013). However, they seem to experience feelings of guilt when classroom time is devoted to the students' L1 (Butzkamm, 2003; Copland \& Neokleous, 2011; Macaro, 2005). Moreover, a wide variation has been observed among teachers and among lessons delivered by the same teacher in terms of the amount of other-language use (Levine, 2011; Macaro, 2001; Polio \& Duff, 1994). Another factor determining the amount of L1 use by the teachers is their learners' language capacities, as teachers tend to use it more with lower proficiency students (e.g., Kharma \& Hajjaj, 2009; Macaro, 1997; Mitchell, 1988).

Several scholars have shared what they consider to be good practices of L1 use to boost the development of multilingualism in a classroom context, building on what research has revealed as natural circumstances of L1 
occurrence. V. Cook's (2001) good practices include, among others, translations by the teacher to explain grammar and vocabulary, L1 use for testing purposes, both in instructions and in activities involving both languages, and L1 use by the students for scaffolding purposes during tasks. Butzkamm and Caldwell (2009), while stressing the fact that the language class provides a unique opportunity for meaning-focused interactions and message negotiation in the language under study, propose that challenging points in classroom communication could be dealt with through use of the sandwich technique. According to this technique, the teacher provides a translation of an unknown expression that has just been used and then repeats it in the target language. Finally, Levine (2011) suggests that simply allowing the L1 in the class is not always effective. He proposes that both teachers and students should become aware of their language choices and proceed to make principled use of their full linguistic repertoires according to commonly decided norms.

Language classes where students do not share the same L1 are an underinvestigated educational setting as far as the use of languages other than the L1 is concerned. Some studies have focused on the role of English as a lingua franca in educational settings at the tertiary level where knowledge of English was either a condition for course enrolment (B. Turnbull, 2018) or anticipated as it involved international university students (Ife, 2008; Wang, 2013). These studies have shown that English was used for both core and framework goals, according to Miles Turnbull's (2000) terminology, by both the teachers and the students.

Even though scholars recognise the need to value students' language backgrounds and acknowledge their constant presence in language classes, few studies have been conducted on whether switching to other languages constitutes a technique more efficient than monolingual teaching. Empirical evidence from vocabulary teaching (Tian \& Macaro 2012; Zhao \& Macaro, 2016) showed some benefit from using L1 codeswitching, as the students offered with an L1 translation equivalent performed better in immediate and delayed recall tests that those offered an L2-only explanation. Furthermore, B. Turnbull and Sweetnam Evans (2017) found that strategic use of the L1 in discussion groups could enhance reading comprehension in the L2.

\section{Sifting Perspectives on Multilingualism and Language Education}

The reassessment of the role already-established languages play in the teaching and learning of an additional language has been fuelled by recent developments in our perception of multilingualism as a dynamic phenomenon. As the study of second language learning has been attracting the interest of researchers from a wide range of fields, such as anthropology, sociology, cognitive science, and education, our understanding of multilingualism and second language learning has been broadened. According to the Douglas Fir Group, a group of celebrated scholars,

Multilinguals are well documented as handling this rich semiotic repertoire flexibly, sometimes keeping the languages separate, at other times alternating them, mixing them, or meshing them. The competence of multilingual speakers is the holistic sum of their multiple-language capacities

(Douglas Fir Group, 2016, p. 26).

In this context, the notion of translanguaging (García, 2009) has been put forward, according to which multilinguals possess a unitary language system, from which they select the features that would best serve the communicative situation at hand (Vogel \& García, 2017). Translanguaging has been proposed as an educational practice (Cenoz, 2017; Cenoz \& Gortner, 2020), mainly in school classrooms with migrant and refugee children as well as in traditional classes where students learn an additional language. In this framework, language instruction is viewed as a process where the teacher nurtures the learners' efforts to integrate more features into their repertoires, which the learners then employ according to their needs (García, 2017).

Moreover, in the educational context, the use of students' L1 has been linked to the notion of investment. According to Darvin and Norton (2018, p. 2), the notion refers to "the commitment to the goals, practices, and identities that constitute the learning process and that are continually negotiated in different social relationships and structures of power". Classroom conditions need to allow for students to express their identities and activate prior knowledge in order to maximise investement; these processes can be effectively served by the students' already-established linguistic repertoires (Cummins, 2001).

The changing perspectives on the language practices of multilinguals and the realisation that keeping languages separate is neither plausible nor constructive in education has opened the way for new directions in 
language classes. One such direction is the integration of 'mediation' in the Common European Framework of Reference for Languages (CEFR) (Council of Europe, 2001). The concept was introduced in the 2001 edition of the CEFR, but has recently been developed further (Council of Europe, 2018) and, as analysed by North and Piccardo (2017, p. 85), includes a linguistic type described as follows:

Linguistic mediation comprises both the interlinguistic and the intralinguistic dimension, which could be in the target language (e.g., summarise an L2 text in L2) or in the source language, including mother tongue. Another form of linguistic mediation is the flexible use of different languages, for example in multilingual classrooms or in everyday professional life.

In another example, the long-neglected practice of pedagogical translation has regained popularity in the relevant literature, as the merits of constructively using this type of activity in language classes are being reassessed (V. Cook, 2010; Tsagari \& Floros, 2013).

In this changing environment, where major advances have been made in scholarly thought regarding the understanding of multilingualism and its development, this study focuses on adult Modern Greek second language education in Greece, where the audience is multilingual and multicultural. Nevertheless, all the participants in the educational process have a linguistic repertoire at their disposal, which may include elements from various languages, some of them shared with others in the same context. To our knowledge, no previous study has focused on this aspect of adult language education in Greece. However, a number of studies focusing on multilingualism in primary and secondary education have concluded that while teachers generally recognise the value of maintaining students' heritage languages, they do not see a place for these languages in school and do not acknowledge their role in their students' academic development (Gkaintartzi et al., 2014; Gkaintartzi \& Tsokalidou, 2011; Mattheoudakis et al., 2017; Mitits, 2018). Given these findings, it is worth investigating adult educators' stance on the issue, i.e., if and how they engage with multilingualism in their teaching practices. Our focus is on how teachers perceive that they deploy their linguistic repertoires and in particular with languages other than Modern Greek, as well as what their views are towards relevant practices. Aiming to shed some light on this issue, our study addresses the following research questions:

1. What are Greek as a second language teachers' views and practices on the use of other languages in the classroom?

2. What are the students' practices with regard to other-language use, as reported by their teachers?

3. Are there statistically significant relationships between teachers' reported practices and their students' use of other languages in class (as reported by the teachers)?

\section{Materials and Methods}

In this study, we pursued a mixed-method design, which allowed for an in-depth investigation of the research questions and the verification of findings from two perspectives. Data was collected through a questionnaire that was administered to teachers online. Additionally, observations of two classrooms were conducted in an Athens-based educational institution offering Modern Greek language classes to adults. According to Creswell and Clark (2017, Chapter 1, The Three Core Mixed Methods Designs section, par. 3) the purpose of the convergent mixed-method design "is to compare the two results with the intent of obtaining a more complete understanding of a problem, to validate one set of findings with the other". In this study the data collected through the questionnaire was analysed to answer all of the research questions. The qualitative data obtained through the observation was collected to support the quantitative data examining other-language use by teachers in L2 Greek classrooms.

\section{Data Collection Tools and Procedures}

The first version of the questionnaire was developed and piloted with two instructors, who filled it out and provided feedback through an interview. The questionnaire was revised and refined in response to their comments. The final questionnaire (Appendix) contained 21 items divided into four sections. Section 1 included items about the teachers' characteristics as well as their typical classes. Section 2 elicited teachers' views and reported practices. Section 3 focused on students' perceptions and practices, while Section 4 investigated the benefits and drawbacks of using other languages in class. All of the sections contained both 
open- and closed-ended questions. The closed-ended questions in Sections 2 to 4 took the form of a 5-point Likert scale. We used open-ended questions whenever we could not predict the full range of possible answers that teachers could offer (Dörnyei, 2003). The questionnaire's final version was administered via the internet using the Google Forms application. Invitations to participate in the study were sent via email to institutions offering courses to adult language learners. In particular, we addressed four institutions in the Athens area, one in Thessaloniki, one in Crete, and one in Ioannina. None of these institutions set any other-language requirements (e.g., English) for class enrolment. In four cases, these institutions were language centres established at universities, offering courses to anyone interested in the language. They are also open to individuals beyond the university's academic community for a fee. The rest were private institutions based in the Athens area, with a curriculum aligned to the CEFR, according to their website ads.

Moreover, observations of two language classes for adult learners of Modern Greek as an L2 were conducted. The classes were part of the programmes offered by the institutions we approached for the questionnaire administration. Given that students' level of proficiency in their L2 determines the amount of L1 use, we opted for classes at lower proficiency levels, where teachers make more extensive use of students' L1 according to the literature (Kharma \& Hajjaj, 2009; Macaro, 1997; Mitchell, 1988). This was expected to increase our chances of recording other-language use for an array of purposes. Moreover, taking into consideration the wide variation among teachers in the amount of other-language use (Levine, 2011; Macaro, 2001; Polio \& Duff, 1994) we decided to observe classes at the same level taught by different teachers, in an effort to capture this variation. Undoubtedly, a comprehensive documentation of teachers' practices would require expanding the research design to include more proficiency levels. Thus, restricting our observation sample to one proficiency level could be considered a limitation of the study.

The observed classes were of A2 level (Council of Europe, 2001) at the time of the observation and were held five days a week. Each class was observed for one lesson, which lasted 2 hours and 15 minutes. Before the observation, both the teachers and the students were informed of the researchers' interest in aspects of the teaching/learning procedure, but no details were given about our specific interest, in an effort to affect normal classroom procedures to the least possible degree. Classroom recordings were not obtainable. The observer sat at the back of each classroom and wrote down instances of instructional practices in the form of field notes. She focused on instances of other-language use by the instructor and towards the instructor, along with information about the general context of use. Moreover, she took notes on the type of activities conducted in class, and the role the teacher and students played in them. The use of observation field notes could be considered a limitation of the present study. Although the researcher tried to make note of all the utterances produced by the teacher and students as accurately as possible, short-term memory limitations may have occasionally undermined the task.

\section{Participants}

The questionnaire was filled out by 30 language teachers, 25 working for language centres established at universities and five employed in private institutions. Of them, $80 \%$ were female and $20 \%$ male, $40 \%$ were in the 31 - to 40 -year-old age range, while $43 \%$ were in the 41 - to 50 -year-old age range. Regarding their education, $60 \%$ held a masters' degree and about $40 \%$ a PhD. The questionnaire did not include a question about their area of specialisation, but the institutions contacted are known to hire teachers with a specialisation in applied linguistics, teaching Modern Greek as a second language, and intercultural education. Approximately $77 \%$ of them had more than ten years of experience in language teaching, while the rest had four to nine years of experience. All teachers spoke Greek as their first language and reported English as an additional language. In a four-point proficiency scale, $90 \%$ of the teachers reported that they had a command of the English language that allowed them to use it for professional, academic, and social purposes. A number of other languages were reportedly spoken by the teachers, among which were French (73\%), German (30\%), and Spanish (30\%) at various proficiency levels.

The teachers observed were women, named Katerina and Maria for the purposes of this study, and both had a masters' degree in teaching Greek as a second language. They both reported a knowledge of English at C2 level, while Maria also reported knowledge of the French language at A2 level. Their teaching experience was 19 and 11 years respectively. Katerina's and Maria's classes hosted 18 and 22 students respectively with a variety of L1s: Chinese, Russian, Bulgarian, German, Albanian, Arabic, Farsi, and Spanish, among others. As a result, both 
classes were linguistically diverse with more than seven first languages spoken in each of them. All of the students held at least a secondary school level certificate, while some held a university degree. No other language knowledge, e.g., English, was a condition for course participation.

\section{Data Analysis}

The closed survey data was analysed via SPSS 19 software. We calculated descriptive statistics and examined relationships between variables. The data from the open-ended questions was analysed through the content analysis method (Dörnyei, 2003). More specifically, each teacher's response was initially marked for key points, and, on the basis of this initial marking, broader thematic categories were formed.

The observation data from the two lessons was carefully inspected and instances of other-language use by the teacher, both productively and receptively, were identified. As a next step, the identified instances of productive other-language use were categorised in terms of the functions they served in the following categories: teaching the target language, classroom management, and affective and interpersonal support. We defined receptive language use by the teacher as instances of other-language use by the students addressing the teacher, in response to which the teacher reacted either verbally in Greek, physically, or by modifying her behaviour. We did not expand our investigation to instances of students addressing other students, although this would potentially reveal more aspects of the role other languages play in the learning process. However, both classes hosted a rather large number of students, who spoke to each other in several languages, as the observation process revealed. Focusing on the languages used by the students would require researchers fluent in a variety of languages. Moreover, monitoring all the interactions occurring simultaneously in class, especially during pair or group work, would require several researchers present in the classroom or multiple recording systems, an endeavour worth pursuing but beyond our means.

\section{Results}

In this section, we first present the findings from the questionnaire, which illustrate the teachers' views and reported practices, as well as the students' practices as viewed by the teachers. A reliability analysis was carried out on the closed-ended Likert scale items of the questionnaire. Cronbach's alpha showed that the questionnaire reached high reliability $(\alpha=0.970)$. Subsequently, the observation results are reported, aiming to substantiate the questionnaire's findings.

\section{The Questionnaire}

The teachers were asked to share information about their typical language classes and their students (Figures 1 and 2). The results indicated that the vast majority of classes were large, consisting of more than 16 students. In these classes, the students spoke a variety of first languages/dialects; $50 \%$ of the teachers reported that four to six different first languages were spoken in their classes, while another $40 \%$ reported more than six languages.

\section{Teachers' Views and Reported Practices}

Regarding the frequency of using other languages at different proficiency levels (Figure 3), it was found that at level $\mathrm{A}$, all of the teachers employed elements of other languages, but a large variation was observed in frequency, as $26 \%$ reported that they used other languages only occasionally, while $20 \%$ used them very frequently. The use of other languages decreased as the student's language level increased.

In an open-ended question, $90 \%$ of the teachers stated that the most commonly used other language was English, while some teachers took advantage of more language resources at their disposal, like Spanish and French, and a few words of the students' other L1s. It is worth noting that $7 \%$ of the teachers reported that no language other than Greek was used. Given the results of the previous question, we assume they taught classes at $\mathrm{B}$ and $\mathrm{C}$ levels. 


\section{Figure 1}

Number of students in a typical class

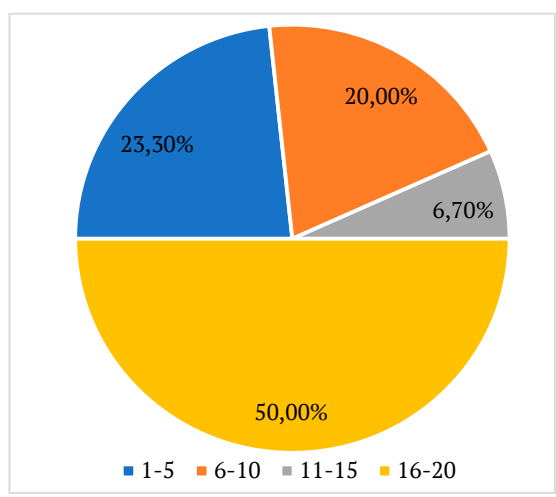

\section{Figure 2}

Number of languages/dialects in class

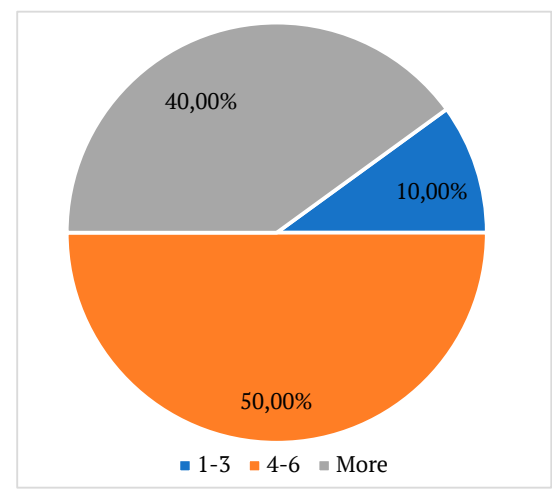

Figure 3

Teachers' reported frequency of using other languages at different proficiency levels

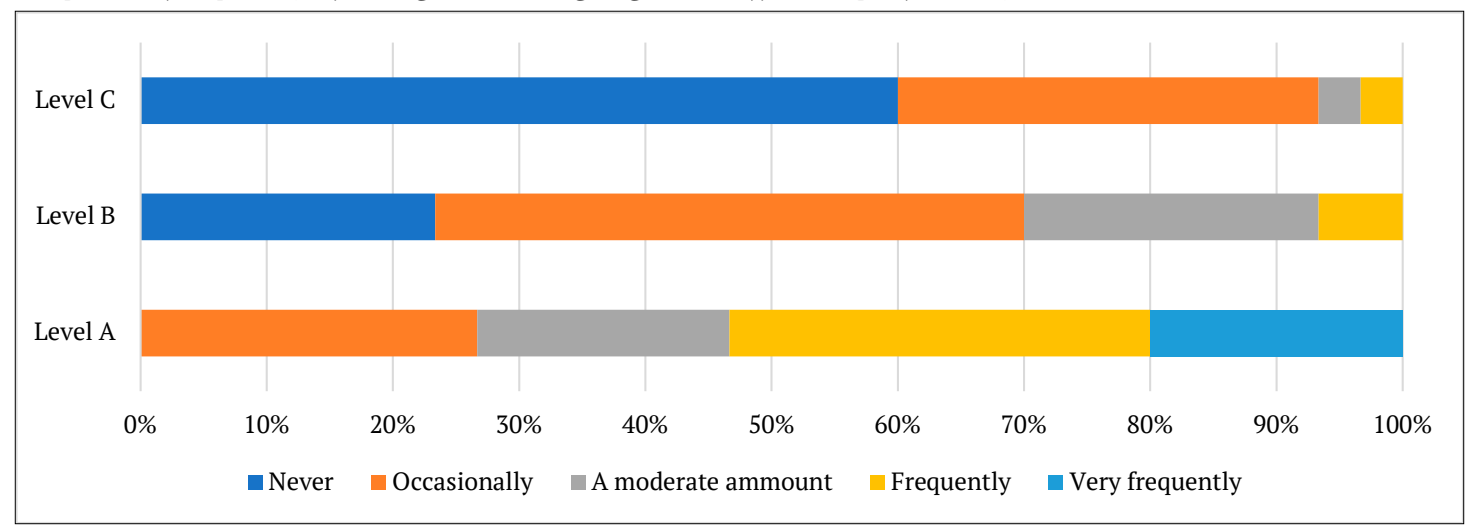

Teachers were also queried about their frequency of use of other languages for specific purposes. Figure 4 visualises the results. Regarding core goals, teachers reported using other languages to explain unknown words and grammar more frequently than to provide feedback and assess students. In fact, the majority of teachers, more than $70 \%$, reported that they almost never used it for the latter two purposes. A substantial variation was observed in the framework goals, either for class management issues or for building rapport with the students. In relation to the first, $10 \%$ of teachers noted that they never use other languages to provide instructions for activities, while $20 \%$ frequently do so. Along the same lines, a large variation among the participant teachers was found regarding the use of other languages to foster personal relationships, as only $10 \%$ of teachers reported that they never use languages other than Greek, while 37\% stated that they use them frequently or very frequently ( $27 \%$ and $10 \%$ respectively).

An open-ended question was used to elicit additional purposes for which teachers use languages other than Greek. Only 11 teachers filled in this question, and out of the 13 purposes mentioned, seven had to do with classroom management (ex. 1), while four of them were cases of affective and interpersonal support (i.e., help with medical exams and doctor's prescriptions). Only two cases of core goals were mentioned, and in both the teachers clarified that the other language was used in one-to-one interactions or after class (ex. 2).

1. "To provide information for procedural issues (e.g., course enrolment issues, absences), but yet again as little as possible".

2. "[...] during the break or after class, to answer their questions (in case they request it)".

All of the teachers stated that they have learned some expressions in the students' $\mathrm{L} 1$, although $40 \%$ follow this practice occasionally (Figure 5). Finally, with regard to encouraging the use of other languages by the students, 
$13 \%$ of the teachers were completely negative towards this idea, while $50 \%$ do not frequently do so. The rest of the participant teachers took a more positive stance towards this strategy.

\section{Figure 4}

Teachers' reported frequency of use of other languages for various functions

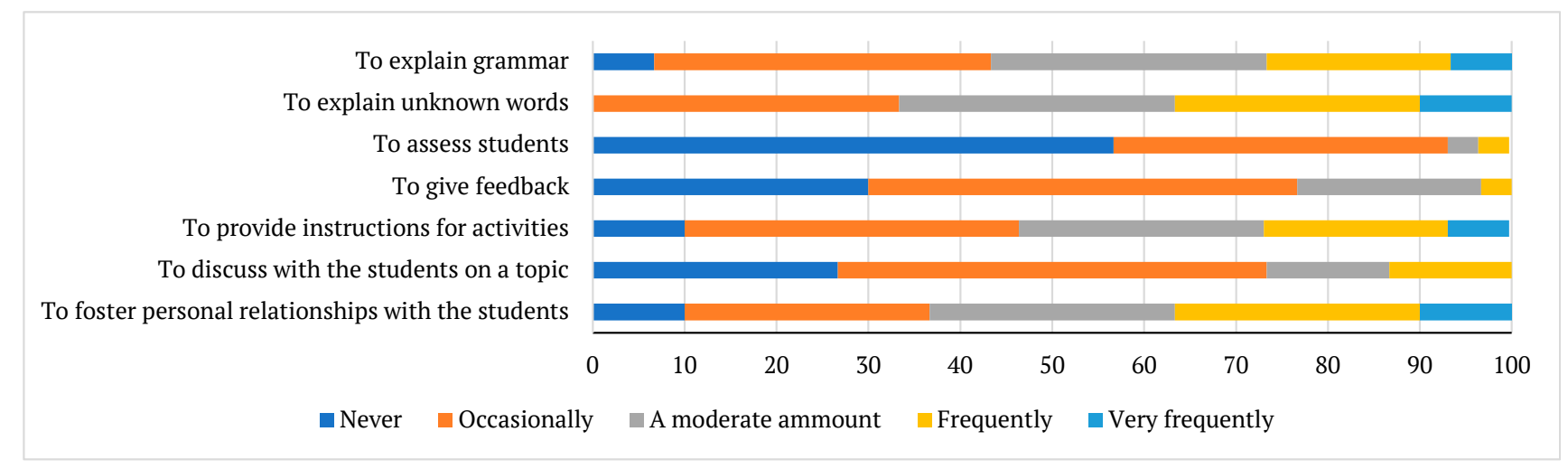

\section{Figure 5}

Teachers' reported practices with regard to other languages use encouragement

Do you learn basic words and expressions in the students' L1?

Do you encourage the use of other languages during the lesson?

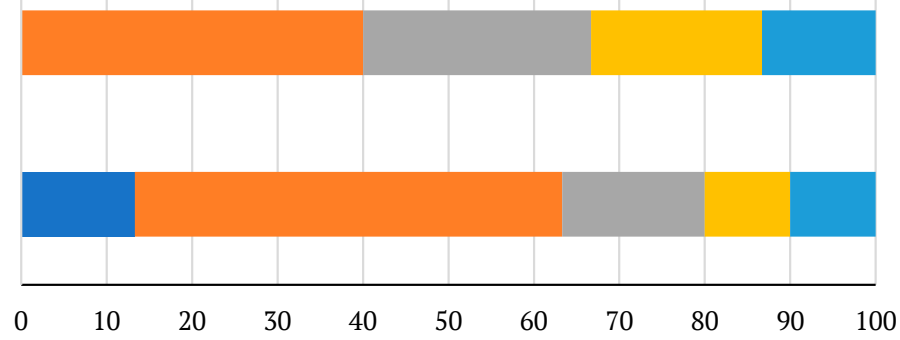

Never $\square$ Occasionally A moderate ammount $\square$ Frequently $\square$ Very frequently

In another open-ended question, teachers were asked about the benefits of using languages other than Modern Greek in class. Twenty of the participant teachers offered their answers, with one of them admitting that (s)he was not in a place to express a scientifically justified opinion on the issue. Some of the answers repeated several of the purposes for using other languages included in previous closed-ended questions. In these cases, the teachers frequently stressed that the use of other languages for these purposes could be considered useful when all other means had failed (ex. 3), thus echoing views claiming that other languages should be avoided.

3. "It can be used as a vocabulary teaching strategy, when the teacher has exhausted all other teaching strategies (definition, imitation, example, image)".

From the qualitative analysis of the rest of the answers, the following themes emerged. The increase of class efficiency and the saving of time was noted by four teachers (ex. 4), while the encouragement of comparison/ contrast among languages was also reported by four teachers (ex. 5). The rest of the answers focused on the affective functions of using languages other than Modern Greek. Four teachers highlighted the other languages' use contribution to relieving students' anxiety, especially at lower proficiency levels. Lastly, three teachers pointed out the establishment of rapport with the teacher and among students (ex. 6).

4. "The use of a mediation language will save time in practical issues, when communication cannot be conducted in the target language". 
5. "Through comparison, similarities and differences between languages are identified".

6. "Mutual understanding among students, establishment of communities and friendships, encouragement, and increased participation in group activities".

The open-ended question about the drawbacks of using other languages was answered by 19 teachers, with two of them stating that there are no drawbacks if the teacher knows how to handle the situation. The content analysis of the rest of the answers yielded the following themes. Firstly, the use of other language(s) was believed to obstruct the learning process, a common view from older approaches to language teaching. In particular, 12 teachers noted that students excessively rely on languages other than Greek to communicate. This slows down the learning process, as they do not take risks in expressing themselves, they do not think in Greek, and they keep needing the mediation of another language (ex. 7). Another dimension emerging from the answers was the students' proficiency level in the language used for mediation. Students who do not speak the language used (e.g., English) are excluded from the educational process and they feel discouraged and frustrated, as five teachers noted. Moreover, students' low proficiency in the mediation language may lead to misunderstandings and confusion (four teachers). A third theme that emerged was interference problems. Four teachers noted that the use of other languages can lead to word-by-word translations and code-mixing, a view reflecting more traditional views on multilingualism. Finally, one teacher noted that the existence of many first languages in class leads to confusion.

7. "The use of other languages usually slows down the development of the target language, because the students resort to the other language, via which it is easier for them to communicate, losing thus the opportunity to utilise everything they have learned and enhance their skills".

\section{Use of Other Languages by the Students}

Teachers reported that students employ their full linguistic repertoire in class and use languages other than Greek for a variety of goals (Figure 6). Relatively high degrees of other-language use were reported for students' explanations to their peers and for clarification requests. In these circumstances, the linguistic repertoire of students is used as a scaffold to assist their language learning. Moreover, students reportedly relied on other languages in message-oriented activities (Butzkamm, 2003), namely when they were eager to express meaning that was important to them, such as to express ideas or opinions on a topic.

\section{Figure 6}

Students' frequency of use of other languages for specific purposes as reported by the teachers

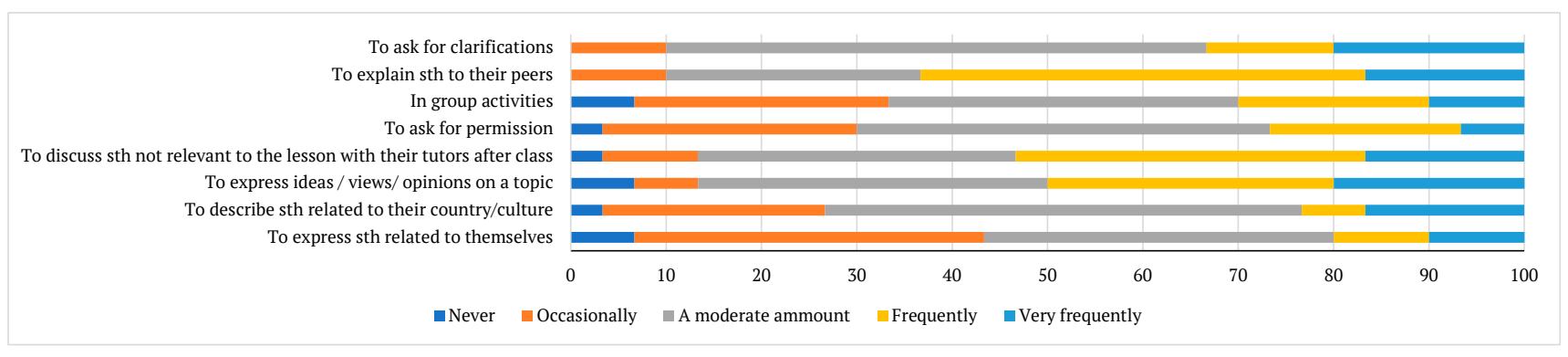

The teachers were also asked to assess how important it was for students to use other languages for a variety of purposes. Spearman correlation coefficients were then calculated between the reported frequency of use and the importance as viewed by the teachers. The results are presented in Table 1. Moderate and strong positive correlations were obtained for almost all purposes, indicating that their assessment of the importance went hand in hand with the frequency they reported. However, the correlation was weak in the case of students providing explanations to their peers. Careful examination of the data revealed that a group of teachers reported the frequent use of other languages by the students to help their peers but considered this function of low importance for them.

In a relevant open-ended question, 11 teachers offered additional purposes for which students use other languages. Five teachers associated the use of other languages with after-class activities and three with 
psychological stress and emotional pressure ("when they are frustrated, sad, or unhappy"). One noted its use for humour, and another one for comments on the topics discussed in class. Finally, one teacher noted that it is used when the teacher provides feedback.

\section{Table 1}

Spearman Correlations between the frequency of other-language use by the students and its importance as viewed by the teachers

\begin{tabular}{|c|c|c|c|c|c|c|c|c|}
\hline & \multicolumn{8}{|c|}{ How important is it for students to use other languages? } \\
\hline & 1 & 2 & 3 & 4 & 5 & 6 & 7 & 8 \\
\hline \multicolumn{9}{|l|}{$\begin{array}{l}\text { How often do the students use languages other than } \\
\text { Greek? }\end{array}$} \\
\hline 1. To ask for clarification & $0.688^{* * *}$ & & & & & & & \\
\hline 2. To explain something to their peers & & $0.391^{*}$ & & & & & & \\
\hline 3. In group activities & & & $0.644^{* * *}$ & & & & & \\
\hline 4. To ask for permission & & & & $0.619^{* * *}$ & & & & \\
\hline $\begin{array}{l}\text { 5. To discuss something not relevant to the lesson with } \\
\text { their tutors }\end{array}$ & & & & & $0.503^{*}$ & & & \\
\hline 6. To express ideas / views/ opinions on a topic & & & & & & $0.717^{* * *}$ & & \\
\hline 7. To describe something related to their country/culture & & & & & & & $0.739^{* * *}$ & \\
\hline 8. To express something related to themselves & & & & & & & & $0.849^{* * * *}$ \\
\hline
\end{tabular}

${ }^{*} \mathrm{p}<.05 .{ }^{* * *} \mathrm{p}<.01$.

\section{Associations Between Teachers’ Views and Students’ Reported Behaviour}

Given the wide variation in teachers' reports of student behaviour for the same purposes, we set out to investigate whether it might reflect the teacher's stance towards other-language use in the classroom. Spearman rank correlations were conducted to investigate relationships between the encouragement of other languages' use by the teachers and the students' reported frequency of use for various purposes. The results are presented in Table 2. A significant, strong correlation was detected with use in group activities, a moderate correlation with other-language use while discussing issues not relevant to the lesson, and a weak correlation with other-language use while describing something related to a student's country or culture. In other words, the teacher's attitude towards other-language use proved to be primarily connected to the students' otherlanguage use to structure and organise the assigned tasks. Furthermore, it was related to providing students with opportunities to share information and participate more fully. Additional correlations were calculated between the teachers' willingness to learn words in the students' L1s and the frequency that students used other languages. However, no significant correlations were detected. 
Table 2

Spearman correlations between the encouragement of other-language use by the teachers and the students' frequency of use for various purposes

Do you encourage the use of other languages in Greek L2 classrooms?

\begin{tabular}{ll}
\hline How often do the students use languages other than Greek for the & \\
following purposes? & 0.311 \\
To ask for clarification & 0.186 \\
To explain something to their peers & $0.664^{* * *}$ \\
In group activities & 0.115 \\
To ask for permission & $0.428^{*}$ \\
To discuss something not relevant to the lesson with their tutors & 0.205 \\
To express ideas / views/ opinions on a topic & $0.391^{*}$ \\
To describe something related to their country/culture & 0.281 \\
To express something related to themselves
\end{tabular}

$* \mathrm{p}<.05 . * * \mathrm{p}<.01$

\section{The Observations}

In this section, the results from the observations are presented. The two observed lessons differed in important ways in terms of the amount and purposes of other languages' use. In order for the reader to form a comprehensive picture of the lessons, each of the classes is described separately.

\section{Maria's Class}

On the day of the observation, Maria's class was exclusively teacher-directed. The class worked together as a group on teacher-led activities. The students also worked individually, performing reading activities and solving a series of grammar drills. No group or pair work tasks were assigned. Maria used the Greek language almost exclusively in the utterances she produced. She used the English language once, to translate a question after an explicit request from a student who could not figure out its meaning through the other means she used to explain it, i.e., a synonym expression and examples of use in context. We categorised this use as an instance of teaching the target language.

Receptively, 14 instances of students' questions and remarks addressed to the teacher were identified. The students used English in all of the cases, while intrasentential code-switching occurred in a few of them. In particular, in five cases, the students asked for the translation equivalent of an English word, forming the question in Greek and inserting the unknown word in English (ex. 8). In all these cases, the teacher responded by providing the word in Greek. In several other cases, Maria addressed a student in Greek and the student responded in English, resulting in bilingual dialogues (ex. 9). Finally, in two instances, Maria asked about the meaning of certain vocabulary items. The students replied in English and then Maria provided a definition in Greek (ex. 10).

\begin{tabular}{|c|c|c|c|}
\hline $\begin{array}{ll}8 & \text { Ti } \\
& \text { What }\end{array}$ & $\begin{array}{l}\text { simeni } \\
\text { means }\end{array}$ & $\begin{array}{l}\text { 'passenger' } \\
\text { 'passenger' }\end{array}$ & $\begin{array}{l}\text { sta } \\
\text { in the }\end{array}$ \\
\hline
\end{tabular}

“What is 'passenger' in Greek?”

9 Teacher: Diavase afto to kimeno.

\footnotetext{
1 The question formation is infelicitous in Modern Greek, as it literally means "What does it mean?".
} 


\section{VICKY KANTZOU, DIMITRA MARIA VASILEIADI}

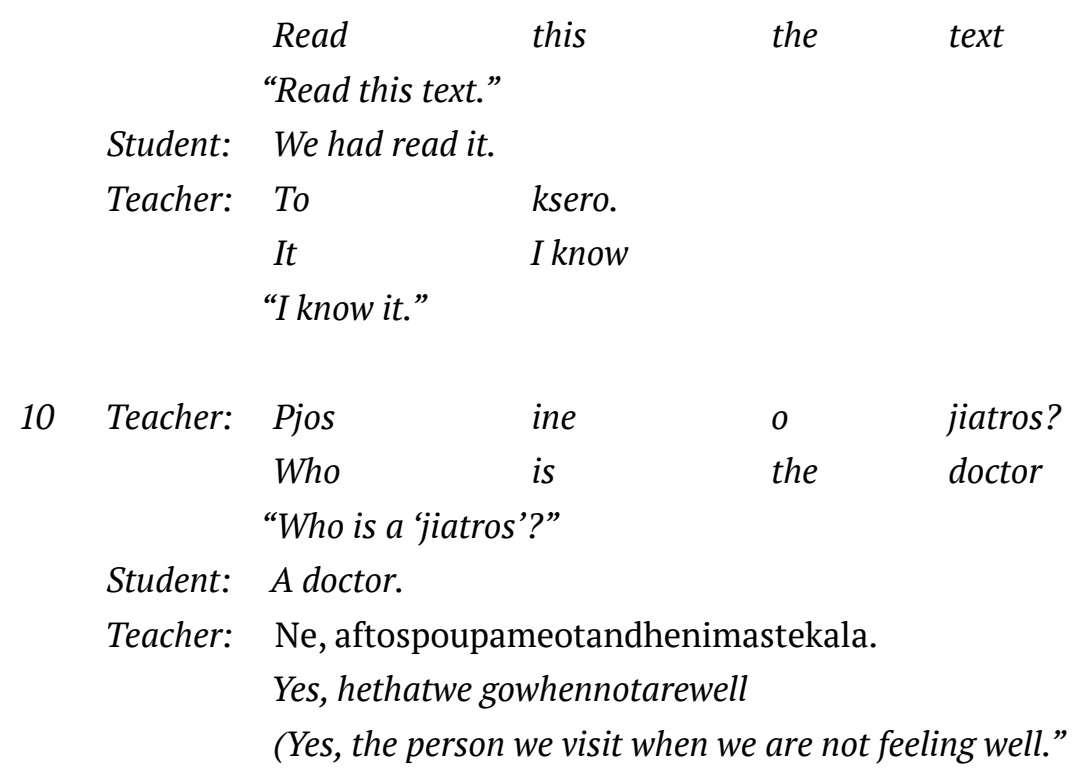

\section{Katerina's Class}

Katerina's class contained both teacher-led and student-centred activities. The student-centred activities involved pair work and a 15-minute presentation given by a student. During this lesson, Katerina made more extensive use of English compared to Maria, but no other language was used. In particular, regarding teaching the target language, 27 instances of productive English use involved translations of vocabulary items. It is worth noting that the use of an English translation was only one of the ways used by the teacher to get the message across. To introduce new vocabulary, Katerina utilised a variety of techniques, i.e., showing pictures, dramatising (e.g., for the word zalizome "to get dizzy"), and giving example sentences to demonstrate the meaning. In three instances, the teacher translated more extended passages of a dialogue the class worked on; in two cases, English was employed for grammar instruction; while in four instances, the teacher gave information about the pragmatics of language use. As for classroom management, five such instances were identified, all involving instructions for classroom activities. An interesting pattern of use when addressing the whole class was that Katerina delivered the instructions in Greek and repeated part of it, words or phrases, translated into English, in an effort, we assume, to clarify the instructions' parts that may have exceeded the students' current language capacities. The technique was reminiscent of the sandwich technique described by Butzkamm and Caldwell (2009). In two of the classroom management instances, Katerina did not address the whole class, but approached a group of students during pair work and explained the task in English, as the instructions in Greek she had previously provided had not been understood by these particular students. Finally, two instances of affective and interpersonal support were found in the data, one when Katerina used English to praise the language production of a lower-level student, and the second one while she was making a joke.

With regard to receptively using other languages, 31 instances were identified, all of which involved the English language. The following contexts of use were observed. Firstly, Katerina treated students' English translations as an indication of word meaning knowledge and text comprehension. The following pattern of interaction was repeated at various points during the lesson: she would ask the students if they knew the meaning of words, phrases, or passages they encountered during reading and listening activities, the students would reply using the English translation equivalent, and Katerina would provide positive feedback to their answers. Secondly, and as was observed in Maria's class too, the students asked for the translation equivalents in Greek of certain words or phrases. This context was particularly frequent during pair work. Moreover, during the presentation, the student resorted to the use of English when she lacked the language resources to express her thoughts. Katerina provided the word or phrase needed in several such cases. Finally, there were cases where the students requested in English more information about something (e.g., is 'na sou po' the same as 'dhe mou les'?). Katerina responded by providing clarifications and examples of use in Greek. 


\section{Discussion}

The present study investigated Modern Greek as a second language teachers' views and perceived practices regarding the use of languages other than the target one when teaching adult learners. It was found that English was the language mainly used in teacher-student(s) interactions, as was expected given that English is the most widely used language in the world today (Eberhard et al., 2019), and has been established as a global language (Crystal, 2003). The students' L1s were not reported or observed to be used in these interactions.

Findings obtained through the analysis of the questionnaire indicated a large variation among teachers in terms of the amount of other-language use in their teaching practices, a conclusion that concurs with earlier studies (Hall \& Cook, 2013; Levine, 2011; Macaro, 2001; Polio \& Duff, 1994). The observation data also documented this variation, as one of the teachers preferred monolingual teaching, keeping the languages apart, while the other made more frequent use of other languages. With regard to monolingual teaching preferences, teachers' views on the disadvantages of using languages other than Greek revealed traditional reservations towards L1 use and especially the assumption that such practices hinder target language development and deprive students of opportunities for language practice (V. Cook, 2001; Macaro, 2005). Moreover, the opinions expressed uncovered views on bilingualism challenged by current academic thought.

Another frequent reservation concerning the use of a language for mediation reflects the multilingual/ multicultural realities of classes and the fact that not all students share a language, and even those who do possess different proficiency levels. Although these are legitimate concerns that need to be addressed, one needs to be careful not to abolish the use of a mediation language altogether, given the benefits of using existing knowledge upon which new knowledge can be built (Cummins, 2007). The observation data offered insights into how teachers who embrace other-language use deal with multilingualism in their class. In particular, one of the teachers used translation as a complementary strategy, employing a variety of other techniques to get the message across, a practice that allowed students with limited knowledge of English to participate in the educational process. Additional strategies could facilitate the learning process, especially during the initial stages of language learning, such as encouraging the creation of student groups on the basis of their mother tongue.

With regard to the main functions of other-language use by teachers, the questionnaire findings and classroom observations converge to determine the frequent other-language use for core classroom goals, and in particular vocabulary teaching, a practice that research has suggested to be effective (Tian \& Macaro 2012; Zhao \& Macaro, 2016). Additionally, the classroom observations revealed another function that was quite frequent in classroom practice; both teachers utilised their students' knowledge of English to monitor their understanding of the target language. This function was not reported in the questionnaire despite being popular among teachers (V. Cook, 2001), perhaps because teachers utilised their knowledge of English receptively and not productively.

Our results regarding the functions of other-language use reflect its utilisation as a scaffold facilitating target language acquisition especially in the initial stages (Kharma \& Hajjaj, 2009; Macaro, 1997; Mitchell, 1988); this scaffold was reported to be gradually removed as students reached higher proficiency levels. Although this function cannot by any means be underestimated, instruction was not reported or observed to focus on the development of interlinguistic mediation skills at all proficiency levels, whose importance is being increasingly recognised in L2 education (Dendrinos, 2006; North \& Piccardo, 2017; Stathopoulou, 2015), given that students need to be prepared to operate in multilingual environments ${ }^{2}$.

These findings lead us to infer that professional guidance in the strategic use of teachers' and students' full linguistic repertoires has been limited, at least for some of the teachers in our sample, with one explicitly stating so. Focused teacher training interventions could help teachers reassess their views on the issue. For instance, Miri, Alibakhshi, and Mostafaei-Alaei, (2017) studied the impact of interventions that are grounded in critical teacher pedagogy and allow participants to problematise the use of students' L1. They concluded that such interventions could lead to critical awareness and changes in teachers' practice. Additionally,

\footnotetext{
2 Council of Europe. (2018). Common European framework of reference for languages: Learning, teaching, assessment companion volume with new descriptors. https://rm.coe.int/cefr-companion-volume-with-new-descriptors-2018/1680787989
} 
professional development interventions should focus on disseminating current understandings of the dynamic nature of multilingualism (Douglas Fir Group, 2016) and translanguaging (Vogel \& García, 2017) as an educational practice (Cenoz, 2017; Cenoz \& Gortner, 2020).

With regard to other-language use by their students, teachers' reports indicated that students often employ their full linguistic repertoires to communicate in class with the teacher and their peers, verifying that this is an inescapable fact in language classes (Hall \& Cook, 2012; V. Cook, 2001). However, there was a wide variation in the reported frequency of other-language use. This finding needs to be studied further, as it may stem from a variety of factors ranging from the teachers' desire to appear in compliance to the old doctrine of monolingual teaching to differences in students' proficiency levels. In this study, we investigated the relationship between the teachers' attitudes towards other-language use and the reported student behaviour. We found a positive correlation with functions that are particularly important for learners and especially adult learners, i.e., the need to control and organise their learning and the need to express their identity. This finding is in line with relevant literature emphasising the cognitive and affective benefits for students when using their L1s (Macaro, 2005; Swain \& Lapkin, 2000).

Finally, the observations revealed a possible source of variation identified in this context that needs to be considered. Teacher-centred activities may elicit less use of other languages, as language input and output are highly controlled and predictable. In student-centred activities where meaning making is central, interactions can be unpredictable and students' target language skills can be challenged. To cope with this challenge, students need to employ their full linguistic repertoires (Alley, 2005; Levine, 2011). Likewise, explaining complex tasks that students are to perform, especially at the initial stages of language acquisition, might be a challenge for teachers, who may also need to deploy elements of their full linguistic repertoires to manage their classes effectively.

A connection between teacher-centredness and students' use of other-languages in class was also hinted at by certain questionnaire data. A group of teachers reported the higher use of other languages in situations where peers support each other in language learning but considered this function of low importance for the students. These views are an indication that those particular teachers were reluctant to cede part of their traditional role to the students, particularly if this was done through the medium of another language. Therefore, teacher education programmes need to address this aspect of classroom practice as well.

\section{Conclusion}

Despite that fact that scholarly thought and empirical evidence offer new perceptions of multilingualism and language teaching, they do not seem to have reached the majority of the teachers in our sample. Our findings have significant implications for teacher training courses, as they highlight the need to educate prospective and in-service teachers on the strategic and principled use of their students' full linguistic repertoires.

Another implication of the present study involves the place of the students' L1s in the educational practice. Given that Modern Greek is learned in a 'majority language' context, including their L1 in the educational process, shows students that their culture and identity is valued in class and, by extension, in the host society. The conditions for the students to invest in classroom practices and language learning could thus be created. However, the teachers participating in this study rarely used the students' language as an organic part of the educational process, although they did seem to be willing to learn elements of these languages in the margins of the educational process. Educational research and practice need to focus on ways to integrate these languages into the curriculum with an emphasis on the mediation aspects of multilingualism.

\section{Conflicts of interest}

The authors declare that they have no conflicts of interest. 


\section{References}

Alley, D. C. (2005). A study of Spanish II high school students' discourse during group work. Foreign Language Annals, 38(2), 250-257. https://doi.org/10.1111/j.1944-9720.2005.tb02489.x

Borg, S. (2003). Teacher cognition in language teaching: A review of research on what language teachers think, know, believe, and do. Language teaching, 36(2), 81-109. https://doi.org/10.1017/S0261444803001903

Butzkamm, W. (2003). We only learn language once. The role of the mother tongue in FL classrooms: Death of a dogma. The Language Learning Journal, 28(1), 29-39. https://doi.org/10.1080/09571730385200181

Butzkamm, W., \& Caldwell, J. A. W. (2009). The bilingual reform: A paradigm shift in foreign language teaching. Gunter Narr.

Cenoz, J. (2017). Translanguaging in school context: International perspectives. Journal of Language, Identity and Education, 16(4), 193-198. https://doi.org/10.1080/15348458.2017.1327816

Cenoz, J., \& Gortner, D. (2020). Teaching English through pedagogical translanguaging. World Englishes, 39(2), 300-311. https://doi.org/10.1111/weng.12462

Cook, G. (2010). Translation in language teaching: An argument for reassessment. Oxford University Press.

Cook, V. (2001). Using the first language in the classroom. Canadian Modern Language Review, 57(3), 402-423. https://doi.org/10.3138/cmlr.57.3.402

Copland, F., \& Neokleous, G. (2011). L1 to teach L2: Complexities and contradictions. ELT Journal, 65(3), 270280. https://doi.org/10.1093/elt/ccq047

Council of Europe. (2001). Common European framework of reference for languages: Learning, teaching, assessment. Cambridge University Press.

Creswell, J. W., \& Clark, V. L. P. (2017). Designing and conducting mixed methods research. Sage publications.

Crystal, D. (2003). English as a global language (2nd ed). Cambridge University Press.

Cummins, J. (2001). Second language teaching for academic success. A framework for school language policy development. In K. Nauclér (Ed), Symposium 2000 - Ett andraspråksperspektiv på lärande (pp. 324-344). Sigma förlag.

Cummins, J. (2007). Rethinking monolingual instructional strategies in multilingual classrooms. Canadian Journal of Applied Linguistics/Revue Canadienne de Linguistique Appliquée, 10(2), 221-240.

Darvin, R., \& Norton, B. (2018). Identity, investment, and TESOL. In J.I. Liontas, T. International Association, \& M. DelliCarpini (Eds.), The TESOL Encyclopedia of English Language Teaching (pp. 1-7). TESOL. https://doi. org/10.1002/9781118784235.eelt0802

Dendrinos, B. (2006). Mediation in communication, language teaching and testing. Journal of Applied Linguistics $22,9-35$.

Dörnyei, Z. (2003). Questionnaires in second language research: Construction, administration, and processing. Routledge.

Douglas Fir Group. (2016). A transdisciplinary framework for SLA in a multilingual world. Modern Language Journal, 100 (Supplement 2016), 19-47. https://doi.org/10.1111/modl.12301

Eberhard, D. M., Simons, G. F., \& Fennig, C. D. (Eds) (2019). Ethnologue: Languages of the world (22nd ed). SIL International.

García, O. (2009). Bilingual education in the 21st century: A global perspective. Blackwell.

García, O. (2017). Problematizing linguistic integration of migrants: The role of translanguaging and language teachers. In J. C. Beacco, H. J. Krumm, D. Little \& P. Thalgott (Eds.), The Linguistic integration of adult migrants: Some lessons from research (pp. 11-26). De Gruyter Mouton.

Gkaintartzi, A., Kiliari, A., \& Tsokalidou, R. (2014). 'Invisible' bilingualism - 'invisible' language ideologies: Greek teachers' attitudes towards immigrant pupils' heritage languages. International Journal of Bilingual Education and Bilingualism, 18(1), 60-72. https://doi.org/10.1080/13670050.2013.877418

Gkaintartzi, A., \& Tsokalidou, R. (2011). 'She is a very good child but she doesn't speak': The invisibility of children's bilingualism and teacher ideology. Journal of Pragmatics, 43(2), 588-601. https://doi.org/10.1016/j. pragma.2010.09.014

Hall, G., \& Cook, G. (2012). Own language use in language teaching and learning. Language Teaching 45(3), 271308. https://doi.org/10.1017/S0261444812000067

Hall, G., \& Cook, G. (2013) Own language use in ELT: Exploring global practices and attitudes. Language Issues: The ESOL Journal, 25(1), 35-43.

Howatt, A. (1984). A history of English language teaching. Oxford University Press.

Ife, A. (2008). A role for English as lingua franca in the foreign language classroom? In E. Alcóm Soler, \& M. P. Safont Jordà (Eds.), Intercultural language use and language learning (pp. 79-100). Springer. 
Kharma, N.N., \& Hajjaj,A.H.(2009).Use of the mother tongue in the ESL classroom.IRAL, 27(3), 223-235. https:// doi.org/10.1515/iral.1989.27.3.223

Krashen, S. D. (1985). The input hypothesis: Issues and implications. Longman

Levine, G. S. (2003). Student and instructor beliefs and attitudes about target language use, first language use, and anxiety: Report of a questionnaire study. The Modern Language Journal, 87(3), 343-364. https://doi. org/10.1111/1540-4781.00194

Levine, G. S. (2011). Code choice in the language classroom. Multilingual Matters.

Littlewood, W., \& Yu, B. (2011). First language and target language in the foreign language classroom. Language Teaching, 44(1), 64-77. https://doi.org/10.1017/S0261444809990310

Long, M. H. (1996). The role of the linguistic environment in second language acquisition. In W. C. Ritchie, \& T. K. Bhatia (Eds), Handbook of research on language acquisition: Second language acquisition (vol. 2, pp. 413-68). Academic Press.

Macaro, E. (1997). Target language, collaborative learning and autonomy. Multilingual Matters.

Macaro, E. (2001). Analysing student teachers' code-switching in foreign language classrooms: Theories and decision making. The Modern Language Journal, 85(4), 531-548. https://doi.org/10.1111/0026-7902.00124

Macaro, E. (2005). Codeswitching in the L2 classroom: A communication and learning strategy. In E. Llurda (Ed.), Non-native language teachers: Perceptions, challenges and contributions to the profession (pp. 63-84). Springer.

Mattheoudakis, M., Chatzidaki, A., \& Maligkoudi, Ch. (2017). Greek teachers' views on linguistic and cultural diversity. In E. Agathopoulou, T. Danavassi, \& L. Efstathiadi (Eds.), Selected Papers on Theoretical and Applied Linguistics, 2, 358-371. https://doi.org/10.26262/istal.v22i0.6003

Mitchell, R. (1988). Communicative language teaching in practice. CILT.

Miri, M., Alibakhshi, G., \& Mostafaei-Alaei, M. (2017). Reshaping teacher cognition about L1 use through critical ELT teacher education. Critical Inquiry in Language Studies, 14(1), 58-98. https://doi.org/10.1080/15427587.2 016.1238286

Mitits, L. (2018). Multilingual students in Greek schools: Teachers' views and teaching practices. Journal of Education and e-Learning Research, 5(1), 28-36. https://doi.org/10.20448/journal.509.2018.51.28.36

North, B., \& Piccardo, E. (2017). Mediation and the social and linguistic integration of migrants: Updating the CEFR descriptors. In J. C. Beacco, H. J. Krumm, D. Little, \& P. Thalgott (Eds.), The linguistic integration of adult migrants: Some lessons from research (pp. 83-89). De Gruyter Mouton.

Polio, C. G., \& Duff, P. A. (1994). Teachers' language use in university foreign language classrooms: A qualitative analysis of English and target language alternation. The Modern Language Journal, 78(3), 313-326. https://doi. org/10.1111/j.1540-4781.1994.tb02045.x

Psaltou-Joycey, A. (2008). Cross-cultural differences in the use of learning strategies by students of Greek as a second language. Journal of Multilingual and Multicultural Development, 29(4), 310-324. https://doi. org/10.1080/01434630802147817

Richards, J. C., \& Rodgers, T. S. (2014). Approaches and methods in language teaching. Cambridge University Press.

Stathopoulou, M. (2015). Cross-language mediation in foreign language teaching and testing. Multilingual Matters.

Storch, N., \& Aldosari, A. (2010). Learners' use of first language (Arabic) in pair work in an EFL class. Language Teaching Research, 14(4), 355-375. https://doi.org/10.1177/1362168810375362

Storch, N., \& Wigglesworth, G. (2003). Is there a role for the use of the L1 in an L2 setting? TESOL quarterly, 37(4), 760-770. https://doi.org/10.2307/3588224

Swain, M., \& Lapkin, S. (2000). Task-based second language learning: The uses of the first language. Language Teaching Research, 4(3), 251-274. https://doi.org/10.1177/136216880000400304

Tian, L., \& Macaro, E. (2012). Comparing the effect of teacher codeswitching with English-only explanations on the vocabulary acquisition of Chinese university students: A lexical focus-on-form study. Language Teaching Research, 16(3), 367-391. https://doi.org/10.1177/1362168812436909

Tsagari, D., \& Floros, G. (2013). Translation in language teaching and assessment. Cambridge Scholars Publishing.

Turnbull, M., \& Arnett, K. (2002). Teachers' uses of the target and first languages in second and foreign language classrooms. Annual Review of Applied Linguistics, 22, 204-218. https://doi.org/10.1017/S0267190502000119

Turnbull, M., \& Dailey-O'Cain, J. (Eds.) (2009). First language use in second and foreign language learning. Multilingual Matters.

Turnbull, B. (2018). The use of English as a lingua franca in the Japanese second language classroom. Journal of English as a Lingua Franca, 7(1), 131-151. https://doi.org/10.1515/jelf-2018-0006

Turnbull, B., \& Sweetnam Evans, M. (2017). L1 and L2 group discussions in L2 reading comprehension. Reading in a Foreign Language, 29(1), 133-154.

Vogel, S., \& García, O. (2017, December). Translanguaging. In G. Noblit, \& L. Moll (Eds.), Oxford research 
encyclopaedia of education. Oxford University Press.

Wang, D. (2013). The use of English as a lingua franca in teaching Chinese as a foreign language: A case study of native Chinese teachers in Beijing. In H. Haberland, D. Lonsmann, \& B. Preisler (Eds.), Language alternation, language choice and language encounter in international tertiary education (pp. 161-177). Springer Dordrecht.

Zhao, T., \& Macaro, E. (2016). What works better for the learning of concrete and abstract words: teachers' L1 use or L2-only explanations? International Journal of Applied Linguistics, 26(1), 75-98. https://doi.org/10.1111/ ijal.12080 


\section{Appendix}

\section{The questionnaire}

Gender:

Female

Age:

18-30 $30-40 \_\quad 40-50 \_$above 50

Years of teaching experience:

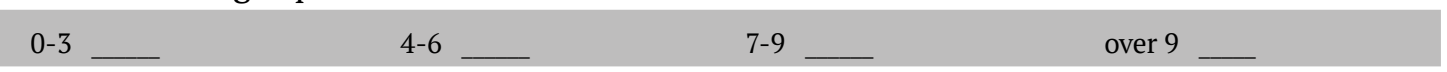

Education:

Bachelor's _ Master's _ $\quad \mathrm{PhD} \_$Postdoc _ $\quad$ Other

First language(s):

Modern Greek Other (specify)

What second/foreign language(s) do you speak?

Proficiency level in each of these languages (in the order mentioned in 6):

Lang. $1 \quad$ Lang. $2 \quad$ Lang. 3

I know key words and expressions. I can communicate in common, everyday communicative situations that require a simple exchange of information.

\begin{tabular}{ccc}
0 & 0 & 0 \\
0 & 0 & 0 \\
0 & 0 & 0 \\
0 & 0 & 0 \\
\hline
\end{tabular}

I can understand the main points of clear standard input on familiar matters. I can produce simple connected text on topics which are familiar or of personal interest.

I can interact with a degree of fluency and spontaneity that makes regular interaction with native speakers possible without strain for either party.

I can use language flexibly and effectively for social, academic, and professional purposes.

What institution/school do you work for?

How many students attend your current class(es)?

$1-5$ _ 6-10 _ $\quad 11-15 \ldots 16-20 \_$Over 20

How many first languages do the students in your class speak?

$1-3$

4-6

More than 6

\section{Section 2}

Do you use any support/mediation language(s) while teaching Modern Greek to students of these proficiency levels?

\begin{tabular}{lccccc}
\hline & Never & Occasionally & A moderate amount & Frequently & Very frequently \\
\hline Level A & 0 & 0 & 0 & 0 & 0 \\
Level B & 0 & 0 & 0 & 0 & 0 \\
Level C & 0 & 0 & 0 & 0 & 0 \\
\hline
\end{tabular}

When you use support/mediation language(s), which is/are it/they? 
How often do you use support/mediation language(s), including the students' L1s, for one of the following purposes?

\begin{tabular}{|c|c|c|c|c|c|}
\hline & Never & Occasionally & A moderate amount & Frequently & Very frequently \\
\hline To explain grammar & 0 & 0 & 0 & 0 & 0 \\
\hline To explain unknown words & 0 & 0 & 0 & 0 & 0 \\
\hline To assess students & 0 & 0 & 0 & 0 & 0 \\
\hline To give feedback & 0 & 0 & 0 & 0 & 0 \\
\hline To provide instructions for activities & 0 & 0 & 0 & 0 & 0 \\
\hline To discuss with the students on a topic & 0 & 0 & 0 & 0 & 0 \\
\hline $\begin{array}{l}\text { To foster personal relationships with the } \\
\text { students }\end{array}$ & 0 & 0 & 0 & 0 & 0 \\
\hline
\end{tabular}

For what other purposes do you use languages other than Modern Greek?

Do you learn basic words and expressions from the students' L1s?

\begin{tabular}{|c|c|c|c|c|}
\hline Never & Occasionally & A moderate amount & Frequently & Very frequently \\
\hline$\circ$ & $\circ$ & 0 & 0 & 0 \\
\hline
\end{tabular}

Do you encourage the use of languages other than Modern Greek during the lesson?

\begin{tabular}{|c|c|c|c|c|}
\hline Never & Occasionally & A moderate amount & Frequently & Very frequently \\
\hline$\circ$ & $\circ$ & $\circ$ & $\bigcirc$ & $\bigcirc$ \\
\hline
\end{tabular}

\section{Section 3}

How often do the students use languages other than Modern Greek for the following purposes?

\begin{tabular}{lccccc}
\hline & Never & Occasionally & A moderate amount & Frequently & Very frequently \\
\hline $\begin{array}{l}\text { To ask for clarification } \\
\text { To explain something to their }\end{array}$ & 0 & 0 & 0 & 0 \\
peers & 0 & 0 & 0 & 0 & 0 \\
$\begin{array}{l}\text { In group activities } \\
\text { To ask for permission }\end{array}$ & 0 & 0 & 0 & 0 \\
$\begin{array}{l}\text { To discuss something not } \\
\text { relevant to the lesson with their } \\
\text { tutors }\end{array}$ & 0 & 0 & 0 & 0 \\
$\begin{array}{l}\text { To express ideas/views/opinions } \\
\text { on a topic }\end{array}$ & 0 & 0 & & 0 \\
$\begin{array}{l}\text { To describe something related to } \\
\text { their country/culture }\end{array}$ & 0 & 0 & 0 & 0 \\
$\begin{array}{l}\text { To express something related to } \\
\text { themselves }\end{array}$ & 0 & 0 & 0 & 0 & 0 \\
\hline
\end{tabular}




\section{VICKY KANTZOU, DIMITRA MARIA VASILEIADI}

For what other purposes, do the students use languages other than Modern Greek in class?

How important is it for students to use other languages, their first language included, for each of the following purposes?

\begin{tabular}{|c|c|c|c|c|c|}
\hline & Not at all & Slightly important & Important & Fairly important & Very important \\
\hline To ask for clarification & 0 & 0 & O & 0 & 0 \\
\hline $\begin{array}{l}\text { To explain something to their } \\
\text { peers }\end{array}$ & O & O & 0 & O & O \\
\hline In group activities & O & O & O & 0 & O \\
\hline To ask for permission & 0 & 0 & 0 & 0 & 0 \\
\hline $\begin{array}{l}\text { To discuss something not } \\
\text { relevant to the lesson with their } \\
\text { tutors }\end{array}$ & 0 & O & O & 0 & 0 \\
\hline $\begin{array}{l}\text { To express ideas/views/opinions } \\
\text { on a topic }\end{array}$ & O & O & O & O & O \\
\hline $\begin{array}{l}\text { To describe something related to } \\
\text { their country/culture }\end{array}$ & 0 & O & O & 0 & O \\
\hline $\begin{array}{l}\text { To express something related to } \\
\text { themselves }\end{array}$ & 0 & O & O & 0 & O \\
\hline
\end{tabular}

\section{Section 4}

What are the benefits of using languages other than Modern Greek in the language classroom?

What are the drawbacks of using languages other than Modern Greek in the language classroom? 